\title{
The initiation of complementary feeding among Qom indigenous people
}

\author{
Sofía Irene Olmedo, B.S. ${ }^{a}$ and Claudia Valeggia, M.D. ${ }^{a, b}$
}

\begin{abstract}
As of six months of life, breastfeeding no longer covers an infant's energy or micronutrient needs, so appropriate complementary feeding should be provided. The objective of this study was to assess the time and adequacy for introducing complementary feeding in a Qom/Toba population and analyze the sociocultural concepts of families regarding complementary feeding. Quantitative and qualitative data were collected by participant observation and semistructured surveys administered to mothers of 0-2 year old infants. Qom breastfeed their infants long term and on demand. Most infants have an adequate nutritional status and start complementary feeding at around 6 months old as per the local health center and international standards. However, mostly due to socioeconomic factors, foods chosen to complement breastfeeding have a relatively scarce nutritional value.
\end{abstract}

Key words: complementary feeding, breastfeeding, infant nutrition, indigenous peoples, Qom.

http:/ /dx.doi.org/10.5546/aap.2014.eng.254

\section{INTRODUCTION}

After the first six months of life, breastfeeding (BF) no longer covers an infant's energy and micronutrient needs; therefore, it is necessary to provide adequate complementary feeding (CF).$^{1,2}$ Among low-income populations, CF is not optimal due to a lack of basic resources (adequate housing, access to potable water) and families physical and mental stress. ${ }^{3}$ This is the situation of most indigenous peoples in Argentina, especially those living in urban and peri-urban regions. In marginal situations, the quality of CF is usually lower than that of BF, CF is started too early or too late, and generally contributes to the substitution of BF. ${ }^{3}$

a. The Chaco Area Reproductive Ecology Program, Fundación Ecosistemas del Chaco Occidental, Formosa, Argentina.

b. Department of Anthropology, University of Pennsylvania, Philadelphia, USA.

E-mail Address:

Sofía Irene Olmedo, B.S.: sofyolmedo12@hotmail.es

Conflict of Interest: None.

Received: 9-13-2013

Accepted: 12-02-2013
Qom (Toba) are indigenous peoples from the Great Chaco region of Argentina. Traditionally, these peoples have been nomad or semi-nomad hunter-gatherers. ${ }^{4}$ The disintegration of their traditional lifestyle and the deterioration of their native habitat have forced these groups to migrate from rural areas to peri-urban locations. ${ }^{5}$ Previous studies have indicated that Qom infants have a generally adequate growth over their first six months of life, but undergo growth failure over their second year of life. ${ }^{6}$ The proportion of malnourished infants peaks at 15 months old. The aim of the study was to evaluate the time and adequacy for introducing CF in a Qom/Toba population and analyze the sociocultural concepts of families regarding this issue.

\section{POPULATION AND METHODS}

This was a descriptive, qualitative-quantitative, cross-sectional study conducted between December 2012 and February 2013 in the Namqom neighborhood, located $11 \mathrm{~km}$ from the city of Formosa. The sociodemographic characteristics of the Namqom neighborhood are described in Table 1.

The sample was made up of $n=19$ girls and $\mathrm{n}=21$ boys of Qom origin ( 2 were $0-4$ months old, 8 were 5-9 months old, 9 were 10-14 months old, 14 were 15-19 months old, and 7 were 2024 months old) and was considered representative of the community (confidence level $=95 \%$ ). Participants were randomly selected from a group of 67 families taking part in a longitudinal study on child growth conducted by the Chaco Area Reproductive Ecology Program.* The protocol was approved by the Ethics Committee of the University of Pennsylvania (\# 811200). Visits were conducted at the houses; during these visits, anthropometric data were recorded and a semistructured interview was performed regarding infant's feeding and health status (Annex 1). Interviews were done in Spanish because all participant mothers are bilingual. Height was measured to the nearest $0.5 \mathrm{~cm}$

\footnotetext{
* For additional information on the program: http:// valeggia.wordpress.com/the-chaco-area- reproductiveecology-program/
} 
TABLE 1. Sociodemographic characteristics of the Namqom neighborhood population in the province of Formosa

\begin{tabular}{lc}
\hline Population size $^{\mathrm{a}}$ & 2500 \\
Approximate number of families $^{\mathrm{a}}$ & 300 \\
Approximate number of families with infants aged 0-2 years old $^{\mathrm{a}}$ & 100 \\
Average number of births per woman (fertility rate) $^{9}$ & 6.7 \\
${\text { Average time between births (in months } \pm \mathrm{SD})^{9}}^{9}$ & $35.6 \pm 21.2$ \\
Interval mode between births (in months) $^{9}$ & $21-33$ \\
${\text { Average duration of breastfeeding (in months } \pm \mathrm{SD})^{9}}^{\text {Average birth weight (boys; in } \mathrm{g} \pm \mathrm{SD})^{6}}$ & $24.3 \pm 11.2$ \\
Average birth weight (girls; in $\mathrm{g} \pm \mathrm{SD})^{6}$ & $3469 \pm 464$ \\
\hline
\end{tabular}

a. Data not published, collected by the Chaco Area Reproductive Ecology Program.

using a portable infantometer SECA $210^{\circledR}$ with the infant in dorsosacral position. Body weight was measured using a digital pediatric scale (Health-O-Meter $549 \mathrm{~K}^{\circledR}$, with a $10 \mathrm{~g}$ accuracy). All measurements were performed by the same person. The tables from the World Health Organization Child Growth Standards (2006)7 were used to classify infants as per their weight, height and age.

The participant observation method was used to complement qualitative data collection. Field and interview notes were analyzed following the grounded theory. ${ }^{8}$ Semistructured interviews were also conducted with six healthcare agents and nurses who work in the Namqom health center (CSN) and who are also members of the Qom community (see annexed survey).

\section{RESULTS}

Half of the infants had a birth weight of $2500 \mathrm{~g}$ to $3500 \mathrm{~g} ; 16 / 40$ had a birth weight of $3501 \mathrm{~g}$ to $3999 \mathrm{~g}$, and $4 / 40$ had a birth weight $\geq 4000 \mathrm{~g}$. The average birth weight was $3430 \mathrm{~g}( \pm 380)$ for boys and $3510 \mathrm{~g}( \pm 520)$ for girls.

Qom infants who participated in this study had an adequate nutritional status (Table 2). No cases of low weight were registered, and there was only one case of nutritional risk as per the body mass index (BMI) for their age. However, $5 / 35$ were classified as having a low height, and 3/40 infants were considered obese.

Most infants were being breastfed at the time of the interview $(33 / 40)$. Besides, $31 / 40$ had started having cow's milk between 0 and 5 months old. Food chosen as the first substitutions of BF were strained rice soup $(10 / 40)$, bread $(8 / 40)$, torta frita (fried dough) $(6 / 40)$ and puffed corn snacks" (5/40). Half of the participants started eating solid food between 5 and 7 months old.
When mothers were asked about who they had asked for advice regarding the time for introducing $\mathrm{CF}, 31 / 40$ said that they had followed the CSN pieces of advice. The rest of the mothers followed cultural traditions encouraged by their own mothers, aunts or grandmothers. There does not seem to be a cultural consensus regarding the appropriate time to initiate CF. Apparently, there are two ideal moments: 1) following the eruption of the first set of teeth (approximately at 6 months old) "or otherwise they lose weight and teeth become decayed," or 2) at 2 or 3 months old "so that the baby eats most foods when he/she grows up." Foods reported as commonly used included apples, bananas, pumpkins, potatoes, and onions. Bread, torta frita and puffed corn snacks are culturally considered to make infants gain weight. Moreover, puffed corned snacks are chosen when children are sick "because they are light." We observed that some infants eat food collected from the municipal garbage dump close to the neighborhood, including dulce de leche (milk candy), yoghourt or cookies.

Based on the analysis of interviews and participant observation, it was seen that economic factors have a substantial weight at the time of choosing breast milk substitutes ("I can only buy yoghourt or more expensive stuff when we get child benefit" or "If we got some dough, we eat well; if we don't, we just have bread or a guachito stew").*

Based on the interviews with the CSN staff, it was stated that mothers are advised to supplement breast milk with potatoes (smashed), pumpkins, rice (soup) and, less frequently, fruits.

\footnotetext{
* Puffed corn snacks are ultra-processed snacks with high salt and fat content.
} 
TABLE 2. Nutritional status of Qom infants who participated in the study as per different indicators

\begin{tabular}{lccc}
\hline & Total & Male infants & Female infants \\
\cline { 2 - 4 } Nutritional indicators & $\mathbf{n}$ & $\mathbf{n}$ & $\mathbf{n}$ \\
\hline By weight/age & & & 5 \\
Overweight & 6 & 1 & 16 \\
Eutrophic & 34 & 0 & 0 \\
At risk of low weight & 0 & 0 & 0 \\
Low weight & 0 & & 20 \\
By height/age & & 15 & 1 \\
Normal height & 35 & 4 & 3 \\
Low height & 5 & & 1 \\
By body mass index/age & & 0 & 8 \\
Obesity & 3 & 1 & 0 \\
Overweight & 2 & 11 & 0 \\
Adequate weight & 19 & 1 & 0 \\
Nutritional risk* & 1 & 0 & 0
\end{tabular}

* This category was used for infants older than 1 year old $(n=25)$.

** Body mass index between the 3rd and 10th percentiles.

They also indicated that, given that they are also part of the community, they understand the economic hardships that families go through and advise mothers to use easily accessible foods that can also be eaten by the whole family.

\section{DISCUSSION}

In general, the nutritional status of infants participating in this study was appropriate for their age, with a normal height and adequate weight for their height. These findings are probably related to the fact that $B F$ is a deeply rooted cultural tradition, and mothers breastfeed on demand until their babies are approximately 3 years old. ${ }^{9}$ However, the quality of complementary feeding is not optimal. It was observed that the state of marginalization suffered by the Qom people has a direct impact on the quality of complementary feeding.

Based on the study limitations (e.g., the small sample size and the probable recall bias), it should be considered a pilot study. However, given the scarce data on infants' nutritional status and on complementary feeding among indigenous peoples in Argentina, we believe that this study constitutes a significant contribution to better understand the weaning process and health of these populations.

\footnotetext{
* Guachito: stew prepared with lots of water and few solid ingredients
}

\section{CONCLUSION}

$\mathrm{BF}$ is a highly prevalent and long term practice among the Namqom community living in peri-urban areas; in general, infants younger than 2 years old have an adequate nutritional status. Although most infants start $\mathrm{CF}$ at around 6 months old, the nutritional quality of such CF is suboptimal; socioeconomic factors have the greatest influence on such poor quality.

\section{Acknowledgments}

This study is part of Sofía Olmedo's B.S. dissertation. We would like to thank Universidad de la Cuenca del Plata (Formosa) professors, the Namqom community, and the financial support provided by the United States National Science Foundation (Career Award \#0952264) and by the National Institute on Aging (NIA P30 AG12836).

\section{REFERENCES}

1. Dewey K. Nutrition, growth, and complementary feeding of the breastfed infant. Pediatr Clin N Am 2001;48(1):87-104.

2. Organización Mundial de la Salud (OMS). La alimentación del lactante y el niño pequeño: Capítulo Modelo para libros de texto dirigidos a estudiantes de medicina y otras ciencias de la salud. Washington, D. C.: Biblioteca Sede OPS; 2010.

3. Burgos G, Carrasco M. Características de la alimentación e ingesta de nutrientes de los niños entre 6 a 24 meses de una comunidad urbano-marginal de Lima (Caso Nievería). Lima: Centro Internacional de la Papa; 2004. 33p. Urban Harvest Working Paper Series, No. 2.

4. Miller ES. Peoples of the Gran Chaco. Greenwood Publishing Group. 1999.

5. Valeggia CR, Lanza NA, Córdoba LI. Fuentes de variación 
en la alimentación actual de los toba-pilagá del oeste formoseño. Actas del Quinto Congreso de Americanistas, 2005; Buenos Aires; Sociedad Argentina de Americanistas; Págs.123-142.

6. Valeggia C, Faulkner K, Ellison PT. Evaluación de curvas de peso en lactantes de una comunidad Toba de Formosa. Arch Argent Pediatr 2002;100(2):31-6.

7. WHOChild GrowthStandards: Methods and development: Length/height-for-age, weight-for-age, weight-for-length, weight-for-height and body mass index-for-age. Geneva: World Health Organization; 2006.
8. Trinidad Requena A, Carrero Planes V, Soriano RMM. Teoría fundamentada, "grounded theory": la construcción de la teoría a través del análisis interpretacional. Cuadernos Metodológicos. Madrid: 2006. Centro de Investigaciones Sociológicas.

9. Valeggia C, Ellison PT. Lactational amenorrhoea in wellnourished Toba women of Formosa, Argentina. J Bios Sc 2004;36(5):573-95.

10. Delucchi M, Fontan M, Grichener S, Wassner M. Proyecto deSaneamiento básico integral: Barrio Namqom, Formosa. Formosa, Argentina: Convenio SDS-UNICEF; 1996. 


\section{Anexx 1}

\section{QUESTIONNAIRE AND SEMISTRUCTURED INTERVIEW CONDUCTED WITH THE MOTHERS OF INFANTS PARTICIPATING IN THIS STUDY}

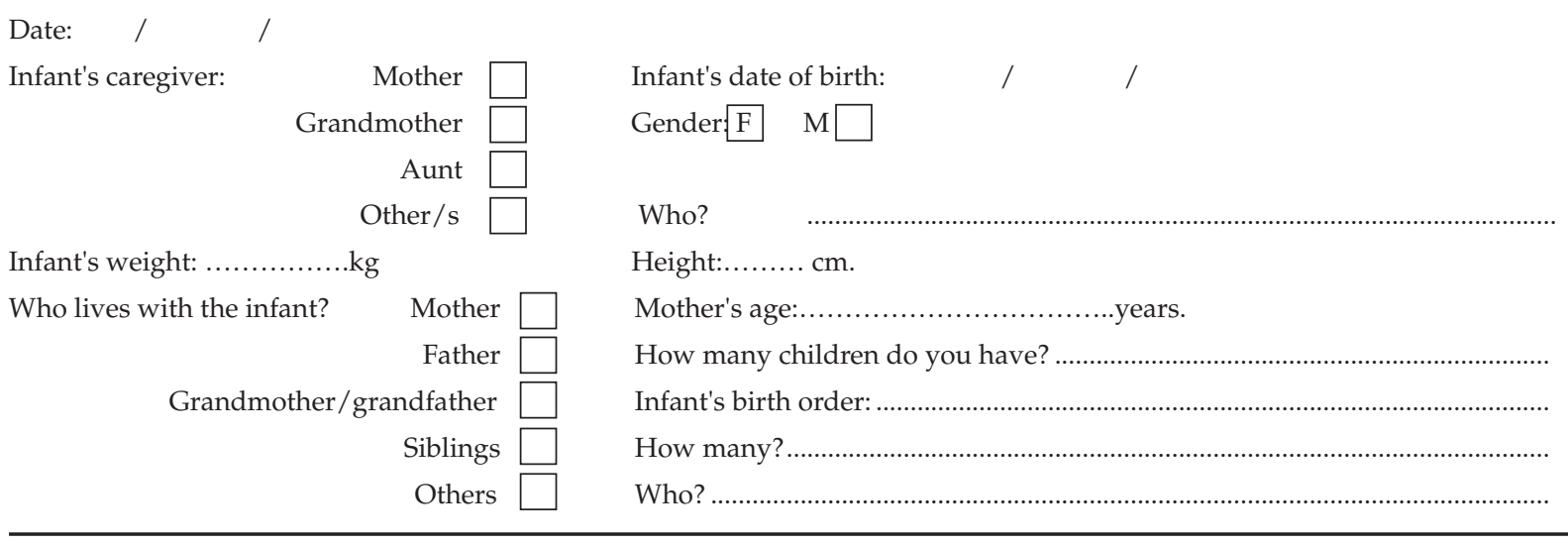

\section{BREASTFEEDING}

Do you breastfeed your child? YES

NO $\square$ Did you breastfeed your child? YES

$\mathrm{NO}$

Up to what age?............months/years old.

Have you considered weaning your child? YES

Why?

NO

Has your child ever had any milk other than breast milk? YES

$\mathrm{NO}$

Which type? Cow's milk

Powder milk

How old was your child when he/she started having other type of milk? days/months/years old.

Did you use a feeding bottle? YES $\square$ NO

Does your child drink other fluids apart from breast milk?

YES

Which fluids?

NO

What container do you use to offer other fluids?

Feeding bottle
Glass/cup $\square$

Beaker

Spoon

\section{COMPLEMENTARY FEEDING}

What was the first food you offered your child?

How did you prepare it?

How old was your child?. days/months/years old.

Why did you decide to give food to your child?

Who gave you information about how to feed your child?

Grandmother $\square \quad$ Doctor at the health center $\square \quad$ Others $\square \quad$ Who? 


\section{Anexx 2}

\section{INTERVIEW WITH THE NAMQOM HEALTH CENTER STAFF}

Gender: F $\square \mathrm{M} \square \quad$ Age..........years.

Profession

1. What do you advice at the health center regarding infant feeding?

2. What do you personally advise?

3. How did you raise your children?

4. When is it common to start feeding an infant?

5. What is the best food for infants? Which food makes them stronger?

6. Why those and not others?

7. When mothers visit the doctor, do they talk about what to feed infants?

8. At home, who says how to raise the child? 